\title{
Factors Towards Voluntary Turnover Among Employees in Malaysia Banking Institution
}

Nurul Ulfa Abdul Aziz, Zalinawati Abdullah, Wan Maziah Wan Ab Razak,
Zainuddin Zakaria, Haszri Faridzuan Bin Zafril, Marha Abdol Ghapar Faculty of Business Management, Universiti Teknologi MARA Cawangan Terengganu, Malaysia

\section{Abstract}

Voluntary Turnover refers to the decision of an employee to leave their organization based on their own intention and self-control. Thus this condition may give negative affects to one organization in terms of monetary, productivity and time deficit. The paper aimed to explore the relationship between factors namely job satisfaction, career adaptability, turnover intention and pay towards voluntary turnover in the banking sector. Self-administered questionnaire is distributed conveniently among respondents from several departments known as Human Resources, Marketing, Retail Rehabilitation, Branch Operation Processing, Treasury and Investigation Audit. The study uses SPSS (Scientific Package for Social Sciences) to specified frequencies distribution, reliability analysis, correlation coefficient (Pearson's) and regression analysis. The analysis proved that there is a significant relationship between voluntary turnover and three independent variables (turnover intention, job satisfaction and pay). The result revealed that the turnover intention is the most influence factor toward voluntary turnover.

Keywords: Voluntary Turnover; Job Satisfaction; Career Adaptability; Turnover Intention; Pay
Publishing services provided by Knowledge E

(c) Nurul Ulfa Abdul Aziz

et al. This article is distributed

under the terms of the

commons Attribution License, which permits unrestricted use and redistribution provided that the original author and source are credited.

Selection and Peer-review under the responsibility of the ICIEBP Conference Committee.

\section{Introduction}

Employee is the main asset in and organization thus the turnover of employee will give a substantial effect towards the financial, emotion and the stability of the organization. Employee turnover can be defined as the number or percentage of workers who leave an organization and are replaced by new employees. There are few factors that contribute towards the turnover of staff such as the condition of the economic changes that forced the organization to cut cost in operation and benefits of the staff and causes discontent while working in the organization. Employee turnover can be divided into two categories which is voluntary and involuntary turnover. Delery, Jenkins., \& Gupta, N. (1998) distinguish that voluntary turnover is reflects by the employee's decision to leave an organization whereas involuntary turnover reflects from employer's decision 
to terminate the employment relationship. Voluntary turnover usually occur when other organization offer better benefits to their potential employee and make the current employee to accept the opportunity presented by others. This situation will cost loss of talent, money and expertise from the previous organization and also forced the organization to hire new employee with less experienced and in need of trainings. To have an insight of this situation this study examined the factors affecting voluntary turnover among employees in Malaysia specifically in the banking sector.

\section{Background Study}

The research is conducted in Menara Kembar Bank Rakyat which is one of the wellknown cooperative banks located in Kuala Lumpur. This study focus on the topic of factors that influence voluntary turnover among employees. Lu et al. (2016) have identify that the main organizational factor influencing employment relationship in an organizational level is the human resource management. Human resource management practices employee promotion and participation of worker which contributes to the employee development and loyalty towards the organization. Huselid (1995) sees human resource is accountable to define employees' capabilities through selected policies, training practices, integrated performance appraisal, competitive rewards and the decision-making made by them. Thus problem regarding employee turnover will directly impacts the human resources management as they are responsible to ensure all talent and asset in forms of human retain in one organization. In Menara Kembar Bank Rakyat, investigation regarding the main reason of employee turnover is still blurry although record show the number of employee turnover are ominously year by year. Therefore this research is conducted to initiate ways in finding the reason and solution concerning voluntary turnover in the banking sector through survey from different departments from the bank such as Human Resources, Marketing, Retail Rehabilitation, Branch Operation Processing, Treasury and Investigation Audit.

\section{Problem Statement}

Employee turnover is one of the issues that affect all organization worldwide. The problem that may occur on the subject of employee turnover is the decrease in productivity. This happen because other workers may have to do the responsibility of the former employee adding to their own current workload until a competent employee can been identify. In addition monetary cost is predicted to happen because the organization 
have to pay additional cost to replace the slack left by the previous employee and also need further cost to advertise, recruit, train and hiring a new staff. If the number of turnover is high than the monetary cost and time span will be obvious and tiring. Bank Rakyat is one of the organizations in banking industry that experienced high employee turnover especially in the year of 2015 onwards. The percentage of the turnover show that there is a significant increase of employee turnover between year 2015 and 2016. The increase of percentage if not be prevented will cause greater problem to the bank organization thus hurdle the bank to move forward in increasing the productivity and profits. Table 1 and Table 2 is the record from the Human Resource Department of Bank Rakyat show the employee turnover rate at Menara Kembar Bank Rakyat since 2015 until 2016.

\section{Voluntary turnover rate $=$ \\ (Number of voluntary leavers /number of people employed) $X 100$}

TABLE 1: 2015 Annual Turnover.

Number of
voluntary
leavers
176

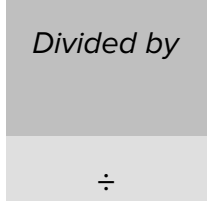

$\div$

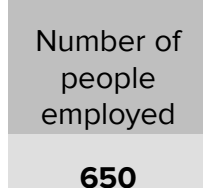

650

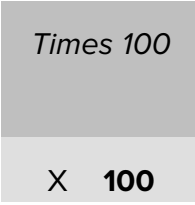

00

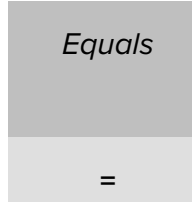

Voluntary turnover rate

\section{$27.08 \%$}

TABLE 2: 2016 Annual Turnover.

Number of
voluntary
leavers
$\mathbf{2 6 1}$

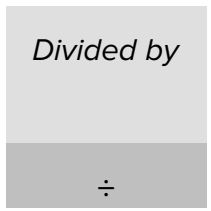

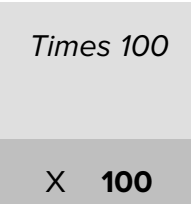

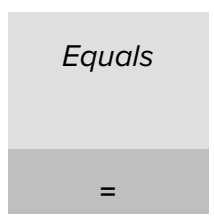

Voluntary turnover rate

$38.38 \%$

\subsection{Objectives of the research}

1. To investigate the relationship of job satisfaction, career adaptability, turnover intention and pay towards voluntary turnover among employees at bank institution namely Bank Rakyat.

2. To identify the most critical factors that influence voluntary turnover among employees at bank institution namely Bank Rakyat. 


\subsection{Research question}

1. What is the relationship between job satisfaction, career adaptability and turnover intention towards voluntary turnover among employees at bank institution namely Bank Rakyat?

2. What is the most critical factor that influence voluntary turnover at bank institution namely Bank Rakyat

\subsection{Research hypothesis}

$\mathrm{H}_{1}$ : There is a significant relationship between job satisfaction and voluntary turnover.

$\mathrm{H}_{2}$ : There is a significant relationship between career adaptability and voluntary turnover

$\mathrm{H}_{3}$ : There is a significant relationship between turnover intention and voluntary turnover

$\mathrm{H}_{4}$ : There is a significant relationship between pay and voluntary turnover.

\subsection{Scope of study}

This research only focus employee that work in Menara Kembar Bank Rakyat Kuala Lumpur. The total number of population in Menara Kembar Bank Rakyat is 1000 whereas the sampling size is 278 employees. The research involved the respondent from several departments in the bank and focuses on the factors that influence voluntary turnover namely job satisfaction, career adaptability, turnover intention and pay. The data is gathered by distributing questionnaires and the information from all respondent is treated as primary data.

\section{Literature Review}

\subsection{Voluntary turnover}

Voluntary turnover according to (Delery, G., \& Gupta, 1998) is the result from employee desires to terminate the relationship with the organization. Mobley (1982) discover that there is only two main reason why employee leave an organization it's either the employee is forced by the management or the employee decide based on their 
own will. Turnover is divided into two main category by Boudreau \& Berger (1985) first is dysfunctional whereby the organization failed to make the employee feel satisfied hence choose to stay in the organization while the second category is functional referred to the company that have poor performance and gain less profit thus forced the employee to leave this concept is also use by Trevor, Gerhart \& Boudreau (1997) in describing turnover. This research focus on dysfunctional turnover that happen based on the employee voluntary intention and decision. Siong et.al (2006) describe the main reason for employee to leave voluntary is because of the emotional effect felt by the employee that cause the employee to search for new jobs from various sources. Voluntary turnover according to Ghadi (2017) creates financial and structural stress on organizational therefore according to Siong et. al. (2006) company need to identify sign of an employee that have potential to leave the company to prevent incur of high cost in recruiting talented employee. Recruit from japan have also agree on the seriousness of this problem therefore they have employs Artificial Intelligent (Al) to stop employee from voluntary turnover. The Al detect workers at risk of leaving the company so that the supervisor can intervene early (Nikkei, 2018) the system will identify employee who likely to quit their jobs within six month. The managers will discuss with the employee about their concern and complaints with the help of Al company able to monitor primary causes for early withdrwal such as variations in performance and working hours. This effort is believed to prevent increasing cost for replacement and recruitment and also indirect costs for morale and training needed in terms of social capital as mention by Dess \& Shaw (2001)

\subsection{Job satisfaction}

McNeese-Smith (1997) define job satisfaction as the pleasing feeling experienced by employees towards their job base on certain aspects such as the salary payment, opportunity and moral support given by the leader of the company. While Radosevich et al. (2008) explain that job satisfaction is produce by employee who have the feeling and action of being engage and committed with the job activities and company's value thus reduces the turnover intention of the employee. This statement is also similar with Siong et. al (2006) description about those who are committed with their job obviously have good attitude and performance as comprised to those who are lacking of commitment. Therefore organizations need to ensure employees obtain job satisfaction in their workplace because obviously job satisfaction have significant influence towards employee performance and commitment to the organization that influence the quality 
of service to the customer and stake holders. Lu et al. (2016) have concluded similarly that job satisfaction is significantly been explain as a positive and important aspect to determine the company performance that is mainly contribute by the employees performance (Chi \& Gursoy, 2009) and also customers valuation towards the service quality and retention (Torres, 2014). Beside that Radosevich et al., 2008; Wefald and Downey, 2009) have found that beneficial that is rewarded by the organizations also is the main factor of job satisfaction this career strategy reduces career concerns of instability and increases job satisfaction. According to Carbery et al. (2003) \& Ghiselli et al. (2001) factors contributing to higher job satisfaction are the salaries, rewards, opportunities and benefits obtain from the organization. Therefore Job satisfaction is considerably important for an employee to remain loyal and reduces the intention to do voluntary turnover thus will create a more stable organization with a good level of service and production.

\subsection{Career adaptability}

Career adaptability is the willingness of individual to accept and deal with any task especially the future task and their readiness to agree with any adjustment and changes of working condition (Savickas, 1997). While Hirschi et al.(2015) define career adaptability as an attitude and behavior of an individual who try to handle with any changes of condition and demand, comprising of four dimension which are concern, control, curiosity and confidence. In detail findings by Koen et al. (2012) proposed that four career adaptability dimensions explain by Hirschi et al. (2015) are malleable rather than the fixed factors. This statement seem alike with Savickas and Porfeli (2012) that describe career adaptability is capabilities that can be develop by those who willing to cope with the future tasks and tend to make adjustments that align with their work roles. Career adaptability helps in maintaining and contributes to the positive career development congruently mention by O'Connell et al. (2008) that career adaptability can be conceptualized as a 'meta competency'. The concept able to forecast the suitable and effective advancement and expertise effectiveness in career development. Prior research also prove that career adaptability is one of the main factor to be consider which affect job satisfaction, workplace attitude as well as career development (Wong, 2015). Obviously if an employee feels that he is getting nowhere within the organization, he will likely be less satisfied and less committed and possibly leave the organization hence contribute to the higher percentage of voluntary turnover. 


\subsection{Turnover intention}

Aydogdu and Asikgil (2011) explained that turnover intentions refer to the attitudes that leads the actions of individual leaving and separating themselves from the organization. Meanwhile Kraut (1975) state turnover intention as a psychological response towards the organizational situation particularly the continuous behavioral that happen during certain condition that bring into being either positive or negative effects. Turnover intention also have been characterized by Tett \& Meyer (1993) as the awareness and deliberate readiness to exit an organization. Jacobs and Roodt (2007) identify that the action to leave the organizations happen based on the individual mental or way of thinking whether the job activity and performance matches their believed and value. There are several reasons that make employees having intention to leave the organization which are related to the job environment, content or design of job, organization such as pay, supervisor or colleague and people such as demographic factors or personality. Kim and Stoner (2008) show concern about the direct negative impact on turnover intention such as social support and job autonomy which also happen based on the result of some external factors such as financial concerns, characteristics of an organization, interpersonal conflicts and alternative employment opportunities (Ganco et al., 2015). Porter and Steers (1973) have counseled that intent to quit the organization is likely the last step prior to quitting. However, behavioral intention to end has been observed to be a strong predictor of personnel turnover throughout industries and theoretically is believed to be an important antecedent to voluntary turnover (Gregory et al., 2007).

\subsection{Pay}

Pay is the level of satisfaction of an employee about their salary which might be difference between their expectation and actual payment ( Jawahar \& Stone, 2011). According to Heneman \& Judge (2000) pay is considered as the most vital organizational prizes agreed also by Rynes, Gerhart \& Minette (2004) that also identify pay as the obvious factor of great importance in the workplace. Normally employees who are satisfied with existing pay system perceives that rewards or incentives are paid with fairness, their seniority is been acknowledge and the performance evaluation is just and reasonable. Although pay is the major reward component in nearly all organizations according to Scott et al. (2008) only few firms spend time and effort communicating to their employees about how pay is determined and allocated. Winter and Jackson (2006) also emphasized the importance of communicating about the management practice as 
it affect employees' satisfaction and cause the employee to stay longer as per evidence show the practice able to enhance organizational commitment, job satisfaction, performance, pay satisfaction and perceptions of reasonable paying, and promoting positive psychological work contracts. Williams et. al (2013) highlighted pay dissatisfaction has been shown to influence cognitions and behaviors, including performance, commitment, trust, misuse, job search, union sentiments, benefit choice, turnover, intention to quit, organizational effectiveness and tardiness.

\section{Methodology and Research Design}

Based on the framework (Figure 1) illustrated four variables known as job satisfaction, career adaptability, turnover intention and pay. This variable is used to access the voluntary turnover among the employees in banking institution

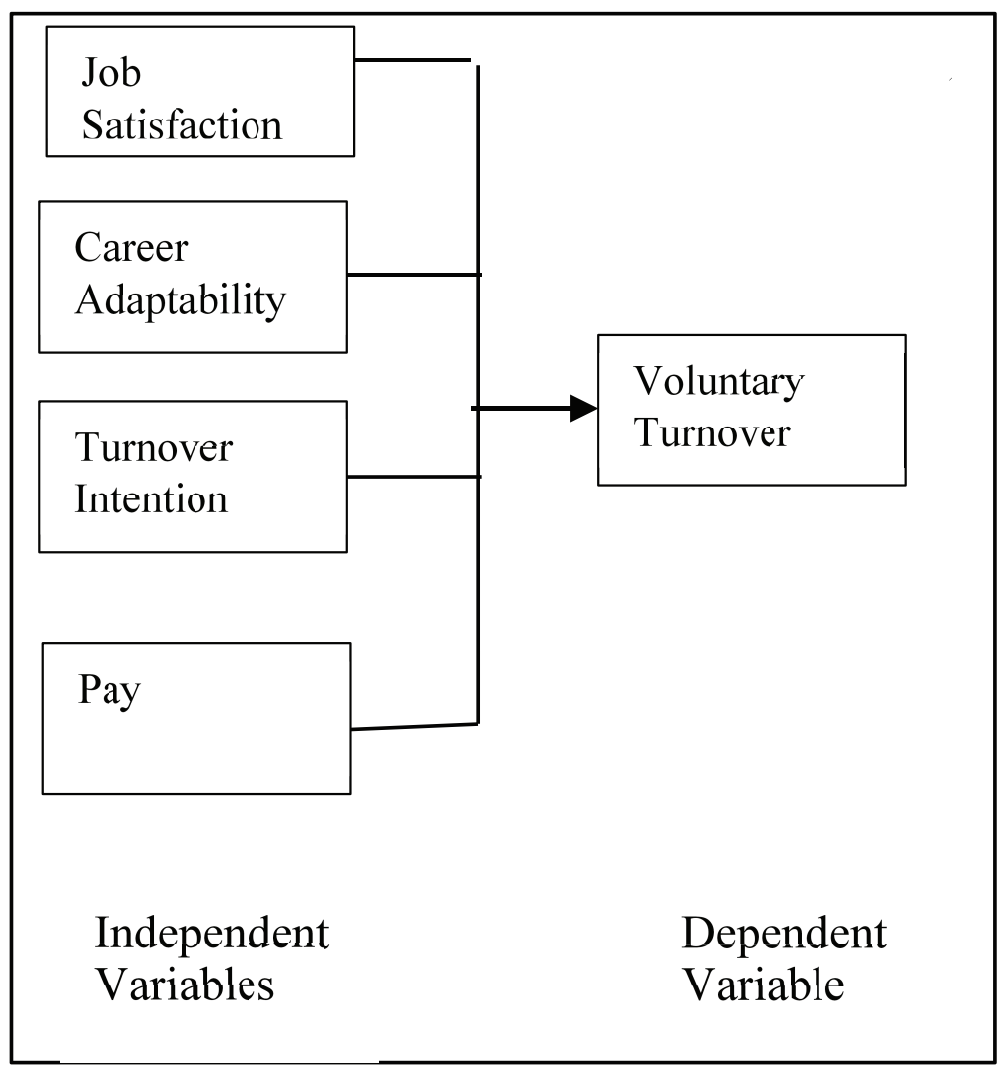

Figure 1: Proposed Framework. 


\subsection{Research design}

The instrument for this study is a questionnaire that contained various questions regarding the information of the dimensions that contributed to the voluntary turnover. All items are measured on a five-point Likert Scale which ranged from (1) "Strongly Disagree" to (5) "Strongly Agree". The questionnaire is divided into 6 sections as follow: 6 questions related to profiles of respondents, 7 questions related to the voluntary turnover, 6 questions on job satisfaction, 6 questions for career adaptability, 6 questions for turnover intention and 6 questions for pay.

\subsection{Sampling Techniques}

Population is a complete group consisting of individuals, object, item or measurements to be taken for the purpose of a survey. The size of a population may be a small or large depending on the objective of a study. Population of this research is mainly around 1000 employees and the sampling size is based to Krejcie and Morgan (1970) suggestion which is 278 employees. Questionnaires for each employee is distributed in different department using convenient sampling technique.

\subsection{Questionnaire design}

Data are collected by using a well-structured questionnaire with questions in prearranged order. The questionnaire items are developed by the researchers to answer the research question. The questionnaire is sectioned into 6 main areas. Section A dealt with the demographic profile which included employees' general information such as gender, age, marital status, education level, position held and length of service with bank. Section B represented the dependent variable which is the voluntary turnover. Section $C$ touched on the first independent variable which is job satisfaction, section $D$ focused on the career adaptability. On the other hand, section E highlighted the third independent variable which is turnover intention. Lastly, section F emphasized on the pay as the fourth independent variable. In sections $B$ until $F$, all items are measured on a five-point Likert Scale ranging from 1-Strongly Disagree, 2-Disagree, 3-Moderate, 4-Agree and 5-Strongly Disagree. 


\subsection{Data collection}

Each employee was given a self-administered questionnaire. To ensure sufficient data gathered accordingly, the researchers met with employees who were in workstation, meeting room, pantry or cafeteria. The average time taken by each respondent was almost 10 to 20 minutes. A total of 300 questionnaires were distributed and 290 (97 percent) were returned. However, 3 sets were discarded due to incomplete data, resulting in merely 287 usable responses.

\section{Analysis and Result}

All values yields alpha coefficient surpasses the values of 0.70 suggested by (Hair et al., 2006). According on the result of Cronbach's Alpha coefficient value, this questionnaire is allowed and applicable. Reliability estimates (Cronbach's Alpha) for the construct's dimension are as follows: Voluntary turnover $(0.838)$ consists of 6 items, job satisfaction (0.824) made up of 7 items, career adaptability (0.766) contains 6 items, turnover intention (0.776) comprises 6 items and pay (0.840) includes 6 items, which all suggesting a high degree of reliability

\subsection{Frequency distribution}

The demographic factors of respondents consist of gender, age, marital status, educational level, position held and length of service with bank. The summary of the demographic factors is shown in the table 3

Based on the table 3 , the result show that there are more female respondents with $51.4 \%$ and $48.6 \%$ of male respondents. Majority of the respondents is $26-35$ years old with the highest percentage of $46.8 \%$. Which is equivalent to 130 respondents. For the marital status, the results show that majority of the respondents is married as recorded the percentage is $62.6 \%$ while the respondents who are single and widower recorded (33.5\%). In term of position held, the majority of the respondents are executive with a number of 174 respondents or $62.6 \%$. While the length of service with the bank, majority of the respondents are working for more than 6 to 10 years with the number of 110 equivalents to $39.6 \%$. Details information is revealed in table 3. 
TABLE 3: Respondent's Demographic Profile.

\begin{tabular}{|c|c|c|c|}
\hline Profile & Description & Responses & $\%$ \\
\hline \multirow[t]{2}{*}{ Gender } & Male & 135 & 48.6 \\
\hline & Female & 143 & 51.4 \\
\hline \multirow[t]{4}{*}{ Age } & $18-25$ & 59 & 21.2 \\
\hline & $26-35$ & 130 & 46.8 \\
\hline & $36-45$ & 59 & 21.2 \\
\hline & 46 and above & 30 & 10.8 \\
\hline \multirow[t]{3}{*}{ Marital status } & Single & 93 & 33.5 \\
\hline & Married & 174 & 62.6 \\
\hline & Widower & 11 & 4.0 \\
\hline \multirow[t]{6}{*}{ Educational Level } & SPM & 19 & 6.8 \\
\hline & STPM & 9 & 3.2 \\
\hline & Diploma & 46 & 16.5 \\
\hline & Degree & 180 & 64.7 \\
\hline & Master & 22 & 7.9 \\
\hline & Others & 2 & .7 \\
\hline \multirow[t]{3}{*}{ Position Held } & Non-Executive & 64 & 23.0 \\
\hline & Executive & 174 & 62.6 \\
\hline & Others & 40 & 14.4 \\
\hline \multirow[t]{5}{*}{ Length of Service in the Bank } & $1-5$ & 35 & 12.6 \\
\hline & $6-10$ & 110 & 39.6 \\
\hline & $10-15$ & 66 & 23.7 \\
\hline & $15-20$ & 35 & 12.6 \\
\hline & 20 and above & 32 & 11.5 \\
\hline
\end{tabular}

\subsection{Correlation among variables}

The analysis for correlation of coefficient was tested by using Pearson's Correlation Matrix. Pearson Correlation is used to test the relationship between dependent variable and independent variables.

As indicated in the table 4 , it show that there are significant relationships between three identifiable independent variables with the main variable of the study. All the three independent variables were significant at 0.01 significant level $(p>0.01)$ based on two-tailed test. However the strength of the relationship differs for certain variables. The result of Pearson Correlation (shown in Table 4) supports the notion that there 
TABLE 4: Correlation among Variables.

\begin{tabular}{|c|c|c|c|c|c|}
\hline Variables & 1 & 2 & 3 & 4 & 5 \\
\hline 1.Voluntary turnover & 1.00 & & & & \\
\hline 2. Job satisfaction & $-0.380^{* *}$ & 1.00 & & & \\
\hline 3.Career Adaptability & -0.074 & $0.422^{* *}$ & 1.00 & & \\
\hline 4.Turnover intention & $0.791^{* *}$ & $0.401^{* *}$ & $-0.184^{* *}$ & 1.00 & \\
\hline 5. Pay & $-0.155^{* *}$ & $0.455^{* *}$ & $-0.227^{* *}$ & $-0.171^{* *}$ & 1.0 \\
\hline
\end{tabular}

is a significantly positive strong relationship between voluntary turnover and turnover intention. The result of correlation between these variable is 0.791 and the significant 0.000 level $(r=0.791, p=0.000)$. On the other hand, voluntary turnover significantly negative relationship with job satisfaction $(r=-0.380, p=0.000)$ and pay $(r=-0.155, p=0.10)$. The strength of correlation between voluntary turnover and with these two variables namely job satisfaction is weak and pay is very weak. These two dimensions of independent variables that consist of job satisfaction and pay differently demonstrated the strength of correlation with voluntary turnover (weak and very weak, respectively). The strength of correlation that has been identified is based on Hair et. al., (2006). For career adaptability dimension, there is no significant relationship with voluntary turnover $(r=0.074, p=0.222)$. Consequently, there is no statistical evidence to support $\mathrm{H} 2$. Meanwhile, there is statistically significant evidence which supports $H 1, H 3$ and $H 4$.

TABLE 5: Summary of hypotheses result.

\begin{tabular}{l|l|l} 
& Hypotheses & Result \\
\hline H1 & $\begin{array}{l}\text { There is a significant relationship between voluntary } \\
\text { turnover and job satisfaction. }\end{array}$ & Supported \\
\hline H2 & $\begin{array}{l}\text { There is a significant relationship between voluntary } \\
\text { turnover and career adaptability. }\end{array}$ & Not Supported \\
\hline H3 & $\begin{array}{l}\text { There is a relationship between voluntary turnover and } \\
\text { turnover intention }\end{array}$ & Supported \\
\hline H4 & $\begin{array}{l}\text { There is a significant relationship between voluntary } \\
\text { turnover and pay. }\end{array}$ & Supported \\
\hline
\end{tabular}

\subsection{Multiple regression analysis}

Further investigation using multiple regression analysis (as shown in Table 6) is also conducted. 
TABLE 6: Summary of regression analysis.

\begin{tabular}{l|c|c|c|c|c|}
\hline Summary R R & ANOVA F Sig. & Dimensions & $\beta$ & $t$ & $p$ \\
\hline $\begin{array}{l}0.802^{a} \\
0.642\end{array}$ & $\begin{array}{l}122.794 \\
0.000^{\circ}\end{array}$ & Job satisfaction & - & - & 0.00 \\
& & 0.1 & 2.8 & 5 \\
\hline & & 31 & 12 \\
& Career adaptability & 0.124 & 3.062 & 0.002 \\
\hline & Turnover Intention & 0.762 & 9.293 & 0.000 \\
\hline & Pay & 0.006 & 0.141 & 0.888 \\
\hline
\end{tabular}

The results show that all dimensions namely job satisfaction, career adaptability, turnover intention and pay contribute significantly ( $F=122.794 ; p=0.000)$ predicting 64.2 percent of the variations in voluntary turnover among employees. Therefore, these dimensions predict a significant change in voluntary turnover.

Further analysis through regression is to measures (Beta value) of the strength for each independent variable which is consist of job satisfaction, career adaptability, turnover intention and pay with voluntary turnover. Beta value $(\beta)$ is used to determine among the independent variables which one has the greatest influence toward dependent variable. Based on the above table, there are three independent variables that are significantly influence toward voluntary turnover which are turnover intention $(\beta=0.762$, $p=0.000<0.05)$, career adaptability $(\beta=0.124, p=0.002<0.05)$ and job satisfaction $(\beta$ $=-1.31, p=0.005<0.05)$. Among all the significant independent variables, the highest standardize beta is turnover intention $(\beta=0.762)$ which is indicate the most critical factors that influence voluntary turnover. This is followed by the independent variable with the second highest Beta value which is career adaptability and last but not least job satisfaction. However, the remaining independent variables which is pay $(\beta=0.06$, $p=0.888>0.05)$ statistically do not influence voluntary turnover. Stated the result shows that the turnover intention is the most influence factor toward voluntary turnover and directly answered the second research questions.

\section{Conclusion}

Referring to table $\mathbf{4}$ of the Pearson Correlation, it indicate the relationship between voluntary turnover and job satisfaction, career adaptability, turnover intention and pay among employees in banking institution. The result of the Pearson's correlation test reveal that there is a strong positive relationship with correlation value of 0.791 between 
voluntary turnover and turnover intention with two-tailed significance test $(p<0.01)$. For job satisfaction and pay factors statistically show that there is negative relationship toward voluntary turnover with low level of strength correlation. It means that the voluntary turnover becomes more decrease with increasing the job satisfaction and pay factors among their employees. But the effect of these two independent variables is very low based on the person correlation and beta values. However, the result of test is not by chance and can be confidently accepted. Turnover intention has been identified to be the most critical factor that highly influence toward voluntary turnover among employees in banking institution. Evidence generated from the regression analysis clearly indicated that $64.2 \%$ variation in the voluntary turnover can be explained by variation in overall independent variables (job satisfaction, career adaptability, turnover intention and pay). In addition, several other dimensions such as job satisfaction, career adaptability and turnover intention were exhibited to be part of contribution factors toward employees' voluntary turnover.

In addition, with the strength of correlation value of 0.791 and significant at $p$ value at 0.000 , clearly strengthened the importance of turnover intention in relation to the voluntary turnover. The relatively significant contribution of turnover intention was further explained by looking at the Beta score of the analysis. From the result of Beta coefficient, the $\beta$ value for the third independent variable, that is turnover intention, was 0.762 , at $p<0.05$ which explained that percentage increase of $76.2 \%$ in turnover intention will increase the voluntary turnover. The management of banking institution should have suitable instrument and procedure in order to identify the suitable person to become their employees. It could be better to have talent management purposely to recognize the candidates that are seriously committed and interested in financial industries specifically banking sector. In meantime, the management team should also improve the pay benefit for their employees. It could be provide in the form of benefit to the employees either in term of monetary (salary, increment, commission, bonus and others) and non-monetary (recognition, retreat, insurance, annual leave, working pattern, flexible working hours and others).

\section{Direction for Future Investigation}

Nowadays, working in banking institutions is quite difficult due too many factors such as economic situation, political environment, purchasing power of customers, the currency rate and management style thus determine the level of voluntary turnover among employees. It could be more interesting if more attempts are considered to include 
the impact of other variables such as government policy/roles, candidate character, management style, facilities and technology provided which have potential capable to decrease the voluntary turnover among employees. Furthermore, extrinsic factor specifically reward not only in term of money but also in term of promotion, fame, grades, praise and intrinsic factor that possibly influence the employee's motivation and encourage loyalty towards the institution. Another important consideration that needed attention is to have a good definition of the population and a more appropriate sampling technique such as using probability approach. By doing this a good generalization for phenomena of the study can be more significant for the decision making.

\section{References}

[1] Aydogdu, S., \& Asikgil, B. (2011). An Empirical Study of the Relationship among Job Satisfaction, Organizational Commitment and Turnover Intention. International Review of Management and Marketing, Vol. 1, No. 3, 43-53.

[2] Boudreau, J. W., \& Berger, C. J. (1985). Decision-theoretic utility analysis applied to employee separations and acquisitions. Journal of Applied Psychology, 70(3), 581.

[3] Carbery, R, Garavan, T.N., O’Brien, F., McDonnell, J. (2003). Predicting Hotel Managers' Turnover Cognitions. Journal of Managerial Psychology, 18 (7): 649-679.

[4] Chi, C.G. and Gursoy, D. (2009) Employee Satisfaction, Customer Satisfaction, and Financial Performance: An Empirical Examination. International Journal of Hospitality Management, 28, 245-253

[5] Delery, J. E., Jenkins, G., D., \& Gupta, N. (1998). An

[6] Organizational-Level Analysis of Voluntary and Involuntary Turnover. Academy of Management Journal, 511-525.

[7] Ghadi, M. Y. (2017). The impact of workplace spirituality on voluntary turnover intentions through loneliness in work. Journal of Economic and Administrative Sciences, 33(1), 81-110.

[8] Ghiselli, R. F., La Lopa, J. M., \& Bai, B. (2001). Job satisfaction, life satisfaction, and turnover intent: Among food-service managers. Cornell Hospitality Quarterly, 42(2), 28

[9] Gregory, D., Way, C., LeFort, S., Barrett, B., \& Parfrey, P. (2007). Predictors of registered nurses' organizational commitment and intent to stay. Health Care Management Review, 32(2), 119-127.

[10] Hair, J., Black, W., Babin, B., Anderson, R., \& Tatham, R. (2006). Multivariate data analysis (6th ed.). Uppersaddle River, N.J.: Pearson Prentice Hall. 
[11] Heneman H.G., III, \& Judge, T.A. (2000). Compensation attitudes. In Rynes, S.L. \& Gerhart, B. (Eds.), Compensation in organizations: Current research and practice (pp. 61-203). San Francisco: Jossey-Bass.

[12] Hirschi, A., \& Abessolo, M., \& Froidevaux, A. (2015). Hope as a resource for career exploration:examining Incremental and cross-lagged effects. Journal of Vocational Behavior, 86, 38-47. doi:10.1016/j.jvb.2014.10.006

[13] Huselid, M. A. 1995. The impact of human resource management practices on turnover, produ.ctivity, and corporate financial performance. Academy of Management Journal, 38: 635-672

[14] Jacobs, E. \& Roodt, G. (2007). The development of a knowledge sharing construct to predict turnover intentions. Aslib Proceedings, 59(3), 229-248

[15] Jawahar, I., \& Stone, T. H. (2011). Fairness perceptions and satisfaction with components of pay satisfaction. Journal of Managerial Psychology, 26(4), 297-312.

[16] Kim, H., Stoner, M. (2008). Burnout and turnover intention among social workers: effects of role stress, job autonomy, and social support. Administration in Social Work, 32(3), 5-25.

[17] Koen, Jessie, Klehe, Ute-Christine, Vianen, Van, \& Annelies, E. M. (2012). Training career adaptability to facilitate a successful school-to-work transition. Journal of Vocational Behavior, 81(3), 395-408.

[18] Kraut, A. I. (1975). Prediction of managerial success by peer and training-staff ratings. Journal of Applied Psychology, 60(1), 14-19. http://dx.doi.org/10.1037/

[19] Krejcie, R. dan Morgan, D. (1970). Determining sample size for research activites. Educational and Psychological Measurement. Vol. 30, 607-610.

[20] Lu, L., Lu, A. C. C., Gursoy, D., \& Neale, N. R. (2016). Work engagement, job satisfaction, and turnover intentions: A comparison between supervisors and linelevel employees. International Journal of Contemporary Hospitality Management, 28(4), 737-761.

[21] McNeese-Smith. (1997) "The influence of manager behaviour on nurses' job satisfaction, productivity, and commitment," Journal of Nursing Administration, vol. 27, no. 9, pp. 47-55,

[22] Mobley, W. H. (1982). Some unanswered questions in turnover and withdrawal research. Academy of Management Review, 7(1), 111-116.

[23] Nikkei. (10 September, 2018). Japan's Recruit employs Al to stop workers from quitting. Retrieved from Nikkei Asian Review: https://asia.nikkei.com/Business/ Companies/Japan-sRecruit-employs-Al-to-stop-workers-from-quitting 
[24] O'Connell, D. J., McNeely, E., \& Hall, D. T. (2008). Unpacking personal adaptability at work. Journal of Leadership \& Organizational Studies, 14(3), 248-259.

[25] Porter, L. W., \& Steers, R. M. (1973). Organizational, work, and personal factors in employee turnover and absenteeism. Psychological Bulletin, 80(2), 151-176

[26] Radosevich, D. J., Radosevich, D. M., Riddle, M. R., \& Hughes, P. A. (2008). Goal orientation as a predictor of cognitive engagement, performance, and satisfaction. Journal of Academy of Business and Economics, 8, 46-55

[27] Rynes, S. L., Gerhart, B. and Minette, K. A. (2004), The importance of pay in employee motivation: Discrepancies between what people say and what they do. Hum. Resour. Manage., 43: 381-394. doi:10.1002/hrm.20031

[28] Shaw, J. D., Delery, J. E., Jenkins, G. D., \& Gupta, N. (1998). An organization-level analysis of voluntary and involuntary turnover. Academy of management journal, 41(5), 511-525.

[29] Savickas, M. (1997). Career Adaptability: An Integrative Construct for Life-Span, LifeSpace Theory. Career Development Quarterly, 45, 247-259. http://dx.doi.org/10. 1002/j.2161-0045.1997.tb00469.x

[30] Savickas, M.L., \& Porfeli, E.J. (2012). Career adapt-abilities scale: construction, reliability, and measurement equivalence across 13 countries. Journal of Vocational Behavior, 80, 661-673.

[31] Scott, K. L., Shaw, J. D., \& Duffy, M. K. (2008). Merit pay raises and organization-based self-esteem. Journal of Organizational Behavior, 29(7), 967-980. DOI: 10.1002/job.539

[32] Siong, Z., Mellor, D., Moore, K. and Firth, L. (2006), "Predicting intention to quit in the call centre industry: does the retail model fit?", Journal of Managerial Psychology, Vol.21No.3,pp.231-24

[33] Tett, R. P., \& Meyer, J. P. (1993). Job satisfaction, organizational commitment, turnover intention, and turnover: Path analyses based on meta-analytic ?ndings. Personnel Psychology, 46, 259-293

[34] Tett, R. P., \& Meyer, J. P. (1993). Job satisfaction, organizational commitment, turnover intention, and turnover: Path analyses based on meta-analytic ?ndings. Personnel Psychology, 46, 259-293

[35] Torres, Edwin N. (2014). Deconstructing service quality and customer satisfaction: Challenges and directions for future research. Journal of Hospitality Marketing \& Management 23: 652-77 
[36] Trevor, C. O., Gerhart, B., \& Boudreau, J. W. (1997). Voluntary turnover and job performance: Curvilinearity and the moderating influences of salary growth and promotions. Journal of Applied Psychology, 82(1), 44.

[37] Williams, N. J., \& Glisson, C. (2013). Reducing turnover is not enough: The need for proficient organizational cultures to support positive youth outcomes in child welfare. Children and youth services review, 35(11), 1871-1877.

[38] Winter, R., \& Jackson, B. (2006) "State of the psychological contract: Manager and employee perspectives within an Australian credit union", Employee Relations, Vol. 28 Issue: 5, pp.421-434, https://doi.org/10.1108/01425450610683636

[39] Wong Humborstad, S. I., \& Perry, C. (2011). Employee empowerment, job satisfaction and organizational commitment: An in-depth empirical investigation. Chinese Management Studies, 5(3), 325-344. 